\title{
Digital Care Providers Antibiotic Prescribing Compared to Traditional Primary Healthcare: A Retrospective Database Study of 332,987 Healthcare Visits in Sweden.
}

Justyna Ivarsson

Umeå University

Thorne Wallman

Uppsala University

Andy Wallman ( $\nabla$ andy.wallman@umu.se )

Umeå University

\section{Research Article}

Keywords: digital care providers, virtual visits, antibiotics, ICD-10-diagnosis codes, Primary Health Care Centre (PHC).

Posted Date: April 14th, 2021

DOl: https://doi.org/10.21203/rs.3.rs-379909/v1

License: (c) (1) This work is licensed under a Creative Commons Attribution 4.0 International License.

Read Full License 


\section{Abstract}

\section{Objectives}

The aim of this study was to examine if there was a difference in antibiotic prescribing between private digital care providers, and traditional primary healthcare, and to investigate if the prescriptions differed regarding diagnosis between virtual visits and physical visits adjusted for age, sex, and place of residence for patients seeking care digitally and in person.

\section{Methods}

Antibiotic prescribing based on ATC-codes during the period of two months in 2020 was studied. Prescriptions issued by online doctors and by physicians working within PHC Sörmland County, Sweden were considered. Information about healthcare provider, date of the visit, staff category that patient had contact with, ICD-10-diagnosis codes, ATC-codes of prescribed medicines and personal information such as: age, sex, and place of residence were used. Statistical analysis and logistic regression were performed.

\section{Results}

Altogether 332,987 healthcare visits were registered. Of all visits to physicians at PHC in Region Sörmland, antibiotics were prescribed in $5.9 \%$ of cases, and $3.9 \%$ of all visits to online doctors. The total number of visits that led to infection diagnosis was 112,354 . Within physical visits at PHC $21.5 \%$ infection visits ended with antibiotic prescription, while within online visits the corresponding percentage was $10.1 \%$. Additionally, the study focused on seventeen infection diagnoses.

\section{Conclusion}

This study has shown that private digital care providers do not prescribe more antibiotics than doctors at PHC. Probability of receiving antibiotic prescription during digital visits was 4.88 times lower compared to physical visits.

\section{Introduction}

"Direct-to-consumer (DTC) telemedicine" includes patient-initiated, on-demand health care with healthcare personnel at a distance [1]. "Virtual visits" are clinical interactions in health care that do not require the patient and the care provider being in the same place at the same moment. "Digital care" is a broader term and covers all interactions in health care that do not require the care provider and the patient being in the same place at the same time [2].

Technology and virtual video visits increase patients' access to healthcare for example, when transport challenges, schedules or physical disabilities can make office visits complicated. It may save lost time at work or at home, travel time, as well as missed and rescheduled assignments [3]. Less travel time and 
waiting time at Primary Health Care Centre (PHC) means less absence from work, which benefits both individuals and employers [4].

Virtual care meetings are a part of Swedish healthcare today, and there are several digital care providers on the Swedish market which makes it possible to get in touch with a doctor within a few minutes. The availability, flexibility, and simplicity at patient's convenience attract many to use the virtual healthcare [5]. But prescribing antibiotics through remote consultations might be expected to be difficult due to the inability to physically examine the patient and perform necessary tests. As the antimicrobial resistance is of global concern, it is of great value to investigate prescribing patterns for digital care providers compared to traditional primary healthcare [6].

It is crucial that antibiotics are prescribed for the right indications and there is a fear that antibiotics might be prescribed more generously at digital care visits [7]. Some articles have indicated that antibiotics are prescribed unnecessarily by online doctors, since private digital care providers do not always have physical healthcare facilities $[8,9,10]$. Questions regarding the risk of overprescribing antibiotics by digital healthcare providers have also been raised in the media [11]. For this reason, The Health and Social Care Inspectorate has inspected (during 2018-2019) thirteen care providers (seven privately and six publicly run), who offered digital healthcare directly to patients and concluded that the conditions were good despite the risk of overprescribing medicines [12].

In Sweden, Primary health care is usually the first instance one turns to in case of illness. One seeks primary care with problems that are not life-threatening. Primary care includes several clinical specialities (including children's clinics, midwife clinics and medical rehabilitation), however the PHC together with digital care are the basis of primary health care [13].

PHC in Sweden is organized and conducted within regions. Regions and municipalities are by law responsible for offering health care within their geographical areas and there can be one or more care providers who deliver health care services. Everyone is free to choose their own health care provider and physician [14].

In Sweden, drugs can primarily be prescribed by licensed doctors and veterinarians. Midwives and nurses who meet special requirements set by the National Board of Health and Welfare may also prescribe certain medicines [15].

In 2019, 6.8 million Swedes (67\% of Swedish population) took at least one drug, of which the largest proportion consisted of the older age groups. Most patients were prescribed paracetamol, omeprazole, and penicillin V. In general, women received prescription drugs more often than men [16].

In 2016, there was an establishment of private digital healthcare companies in Sweden, such as Kry, Min Doktor and Doktor24, which have developed services that make it easy to access healthcare via a smartphone or a computer [4]. Three Swedish online medical companies (Kry, Min Doktor and Doktor.se) have together a market share of approximately 90 percent in terms of digital healthcare (Figure 1). By 
2020, the four largest digital healthcare companies had their seats in Region Sörmland [17]. The Swedish digital care is designed to work as a part of the Swedish welfare system. This means that main costs are reimbursed by the social welfare system. In addition, patients pay a fee for a physical care visit as well as they pay a fee for a digital visit (in this case patient visits within Region Sörmland were free) [18].

In 2016, the so-called out-of-county compensation was SEK 2195 per care visit, which minus patient and administration fees gave the physical and digital healthcare providers approximately SEK 1700 . Since then, the compensation has been gradually reduced.

At the beginning of 2017, a special fee for web-based doctor visits was introduced and amounted to SEK 1200. During the same year, the total remuneration for digital visits was further reduced and set to SEK 650 , including the out-of-pocket patient fee where such was paid $[4,18]$. In 2019 , Sweden's Municipalities and Regions reduced remuneration for digital care services even more and now digital healthcare companies receive SEK 500 (equivalent to 50 EURO) for a virtual doctor's visit [19].

Digital healthcare has many advantages. Virtual visits save time for patients and at the same time increase doctors' working time flexibility and availability, including evening and weekends. Patients do not need to travel to meet a doctor which reduces the risk of contagion at PHC and on the way to them. Digital care can also potentially improve access to care for inhabitants living in rural areas of Sweden. In cases of making simple diagnoses and issuing prescriptions, easier access to primary care provided by digital medical companies has the potential to shorten queues for the traditional primary care at PHC $[4,18]$.

Previous studies have shown that virtual care is used mostly by parents of small children and residents of large cities. In large Swedish metropolitan areas, it has been observed that women in their early twenties used digital care the most [20]. Critics of telemedicine often mention a lack of continuity and an overconsumption of care, which can generate high costs for the public welfare system. Another disadvantage of digital healthcare is that it is not always possible to examine the patient via a video call, as it is in case of ear infections, tonsillitis, or pneumonia [4,8,21]. Last, but not least, there is a debate in Sweden that digital doctors overprescribe drugs and antibiotics in particular $[8,9]$.

There is a growing competition between digital care provider companies, and they compete by creating greater benefits for customers. More and more cooperation between digital healthcare companies and pharmacies is being witnessed. In the beginning of 2020, the state-owned pharmacy chain Apoteket AB bought 20 percent of the digital care company - Doktor24, while the ICA group, who is the owner of second largest pharmacy chain Apotek Hjärtat, bought another digital medical company in 2018 - Min Doktor [22]. By the end of 2019, the Swedish Medical Products Agency proposed that healthcare providers should not be allowed to own pharmacies and the other way around. It indicated the risk that a joint ownership of care providers and pharmacies could lead to increased prescribing of drugs and increased care consumption, example, in form of an "unnecessary" referral to care providers from pharmacies [23]. However, digital healthcare providers are being more and more integrated with pharmacies. 
Antibiotics are prescription drugs used to treat bacterial infections. There are several types of antibiotics that work against different types of bacteria, thus it is important to use the correct type of antibiotic [24]. Frequent use of antibiotics leads to antibiotic resistance, making bacterial infections difficult to cure. As antibiotic resistance is a growing public health problem, it is important that antibiotics are used rationally - only when they are needed [25].

STRAMA, (the Strategy Group for Rational Antibiotic Use and Reduced Antibiotic Resistance), whose objective is to counteract antibiotic resistance, exists in Sweden, and Sweden has a leading position in the world in appropriate use of antibiotics. This national collaboration includes training of healthcare professionals in the wise use of antibiotics and recommendations for treatment of common infections [26].

It is said that online doctors in Sweden are not as thorough as physicians in PHC in following STRAMA's guidelines and recommendations and therefore prescribe antibiotics more often [8,9]. However, there are studies indicating lower prescribing of antibiotics in remote consultations compared to face-to-face consultations [6,27]. One study showed that adult patients presenting with sinusitis, received a higher rate of guideline-concordant diagnosis and a lower prescription of antibiotics at virtual visits compared with in-office primary care visits. So, the virtual patients received more often an appropriate diagnosis of viral sinusitis, which implies a lower rate of antibiotic prescribing [27]. Other studies demonstrated no difference $[28,29,30,31]$. One study found no difference in antibiotic prescribing for acute respiratory infection amongst patients seen by telemedicine and patients seen in person at physician's office [28]. Another study claimed that management of urinary tract infections via DTC telemedicine is appropriate for most average-risk female patients, confirming that the national guidelines were followed in the majority of cases [29]. An American study showed that there was no difference in prescribing, labs and images ordered by online doctors and physicians met in person for most of the twenty studied diagnoses. However, the report noticed that patients seeking for anxiety and depression would rather have a virtual visit than in-office [30]. A randomised controlled trial demonstrated no difference and showed similar clinical outcomes for patients with diabetes mellitus having telemedicine video consultations compared to in-clinic consultations. However, greater satisfaction regarding the type of consultation (videoconferencing versus physical visit at clinic) was observed among patients and primary care providers who used telemedicine consultations [31].

On the other hand, there are studies which demonstrate higher antibiotic prescribing rates for DTC telemedicine than for in-office visits [6]. For example, antibiotic prescribing was found to be higher for direct-to-consumer telemedicine among children 0-17 years compared with urgent care and primary care provider offices. In addition, concordance to antibiotic prescribing guidelines was lower for DTC telemedicine than for the other two mentioned care providers [32]. As antibiotic resistance is a serious and growing problem worldwide, it is important to study whether there is a difference in antibiotic prescribing patterns between digital healthcare providers and traditional primary healthcare. 
Prescribing of antibiotics in Sweden has decreased by more than a quarter over the past ten years [33]. In 2011, STRAMA had set a goal for antibiotic prescribing, which was issuing a maximum of 250 antibiotic prescriptions per 1000 inhabitants and year by 2014. Although the goal was not achieved by this year and there are differences among various Swedish regions - the goal was an important factor that contributed to the overall reduction [34]. Sweden has a long experience of improving the use of antibiotics and is in the lead among European countries, nevertheless, it is considered essential to continue this work [35].

There are almost no scientifically reviewed studies that have compared Swedish digital care providers and traditional primary healthcare physicians and their prescribing habits. There are many American studies in this field $[3,27,28,29,30,31,32]$ and some European ones [6], therefore it is of great value to investigate antibiotic prescribing patterns in Sweden, which is why this study was undertaken.

\section{Objective}

The aim of this study was to examine if there is a difference in antibiotic prescription patterns between physicians meeting patients online, and physicians meeting their patients in person, in a traditional primary care environment at the PHC in Region Sörmland, Sweden. As for the digital healthcare providers, the study included four nationwide companies: Kry, Min Doktor, Doktor.se and Doktor24. Additionally, the study's aim was to investigate whether the prescriptions differ in terms of diagnosis between virtual visits and physical visits at PHC. The study also looked at differences in age, sex, and place of residence for patients seeking care digitally and in person at PHC.

\section{Methods}

The study examined antibiotic prescribing based on ATC-codes (Anatomical Therapeutic Chemical Classification System) [36] during a period of two months: from January to February 2020. Prescriptions issued by online doctors from four private companies registered in Region Sörmland: Kry, Min Doktor, Doktor.se, Doktor24 and by physicians working within Primary Health Care Sörmland were regarded and included.

Inclusion criteria were those prescriptions whose ATC-codes contained drugs in ATC-group J01 (Antibacterials for systemic use), excluding J01XX05 - methenamine. These criteria were chosen on the basis of the recommendations from the National Board of Health and Welfare [37], Sweden's Municipalities and Regions [33], STRAMA [38] and WHO Collaborating Centre for Drug Statistics Methodology [39]. The usage of ATC-codes for identifying antibiotic prescriptions and ICD-10-diagnosis codes are not unique and were commonly employed in many similar studies $[27,28,29,30,32]$. Infection diagnoses were selected in order to determine if there is a difference in antibiotic prescription patterns between private digital care providers and traditional primary healthcare. Guidelines and a list of diagnosis codes, ICD-10 (10th revision of the International Statistical Classification of Diseases and Related Health Problems), that Public Health Agency of Sweden suggested to be used for the purposes of 
monitoring, analysing, and assessing whether antibiotics were used according to guidelines, are found in its document [40]. This list facilitated studying of diagnostic-linked antibiotic prescribing. If a person had received an infection diagnosis it was analysed as to whether the diagnosis led to antibiotic prescribing. In this way it was possible to answer the query of how large the proportion of antibiotic prescribing was within the groups of patients that obtained an infection diagnosis.

Digital care providers sent the information about their online visits via a system called Privera. Via this database a number of parameters were then transferred to Region Sörmland's system called BORIS. Data regarding the physical PHC was also obtained from BORIS database and from the medical record system NCS Cross, which are both commonly used within Region Sörmland. Information that was obtained from databases were: healthcare provider, date of the visit, staff category that patient had contact with, ICD-10diagnosis codes, ATC-codes of prescribed medicines as well as personal information such as: age, sex, and place of residence.

The statistical analysis consisted of Z-test for two-proportions [41]. The null hypothesis was that there is no difference in antibiotic prescriptions patterns between online doctors and physicians working at the PHC. The alternative hypothesis was that the virtual visits led to more antibiotic prescriptions. With power of $80 \%$, alpha 0.05 and $5 \%$ statistically significant difference it was calculated that the sample size in each group should be at least 1227 visits. Chi-square test and calculations were performed using SPSS [42]. After investigating if there was a difference in proportions between the two groups, a logistic regression with the antibiotic prescription as an outcome was performed. Type of healthcare visit was used as an explanatory variable, while age, sex, and type of infection were used as confounders to adjust for the differences that existed between the virtual and physical visits.

\section{Ethical considerations}

The study was conducted in Region Sörmland, Sweden. It is a retrospective registry-based study where all sensitive patient data was encrypted using a key code. The key code was created by a person outside the research group and was stored securely. Thus, the personal integrity of the studied patients was not affected, since the social security numbers were coded and replaced with different numbers so that the individuals could not be identified. As the study was an observational study without any form of intervention only aggregated data was presented and all sensitive data was destroyed after the research was completed.

The ethical application for this study was approved by the Swedish Ethical Review Authority [43,44], diary number 2020-04098.

\section{Results}

\section{Study population}


During the period from January to February 2020, there were 332,987 visits, both to online doctors and physical visits to PHC in Region Sörmland. In the data set, the total number of physical visits within Region Sörmland was 88,871 and they were made by 54,070 individuals (residents in Södermanland's county), while the total number of online visits was 244,116 and they were made by 194,006 individuals (residents nationwide).

The characteristics of people seeking medical care varied when it came to the type of visit (online versus in person) between these two groups. Among physical visits, the highest proportion of patients were between 60 and 80 years old. Whereas virtual visits were mainly used by women in their twenties and by parents of small children, Figure 2. In general, women sought medical attention more often than men.

Virtual visits originated from densely populated areas in Sweden with cities - Stockholm, Gothenburg, and Malmö. 2.5\% of all virtual visits were visits made by residents living within Region Sörmland, Figure 3.

\section{Proportions of prescribed antibiotics}

Out of all physical visits at PHC, in $5.9 \%$ of cases antibiotics were prescribed, (during 5203 visits). Out of all visits to online doctors, $3.9 \%$ of cases were prescribed antibiotics, (during 9427 visits). This difference in antibiotic prescribing ( $5.9 \%$ versus $3.9 \%)$ was statistically significant.

The total number of visits that led to the diagnosis of infection was 112,354 . Within physical visits at PHC 21.5\% infection visits ended with antibiotic prescription, whereas within online visits $10.1 \%$ infection visits ended with antibiotic prescription. The difference in antibiotic prescribing (21.5\% versus $10.1 \%)$, was statistically significant.

Out of the visits involving an infection diagnosis, seventeen were analysed to determine whether a person who had been diagnosed with an infection also received a prescription for antibiotics, Table 1. In total, 66,216 infection diagnoses were considered.

Table 1. Proportions of prescribed antibiotics in infectious diseases ( $P$ value determined from $\chi^{2}$ test) 


\begin{tabular}{|c|c|c|c|c|c|}
\hline \multirow[b]{2}{*}{ INFECTIOUS DISEASES } & \multicolumn{2}{|c|}{ PHC } & \multicolumn{2}{|c|}{ DIGITAL } & \multirow[b]{2}{*}{$\begin{array}{c}P \\
\text { value }\end{array}$} \\
\hline & $\begin{array}{l}\text { Total No } \\
\text { of visits }\end{array}$ & $\begin{array}{c}\text { Antibiotics } \\
\text { prescribed \% } \\
\text { (n) }\end{array}$ & $\begin{array}{l}\text { Total No } \\
\text { of visits }\end{array}$ & $\begin{array}{c}\text { Antibiotics } \\
\text { prescribed, \% (n) }\end{array}$ & \\
\hline ACUTE BRONCHITIS & 752 & $25.9 \%(195)$ & 738 & $0.8 \%(6)$ & $<0.001$ \\
\hline ACUTE CYSTITIS & 1445 & $83.0 \%(1200)$ & 6550 & $78.0 \%(5109)$ & $<0.001$ \\
\hline ACUTE OTITIS MEDIA & 909 & $82.5 \%(750)$ & 429 & $56.2 \%(241)$ & $<0.001$ \\
\hline ACUTE RHINOSINUSITIS & 377 & $62.1 \%(234)$ & 2765 & $7.3 \%(201)$ & $<0.001$ \\
\hline ACNE & 242 & $24.0 \%(58)$ & 5001 & $21.5 \%(1076)$ & 0.366 \\
\hline $\begin{array}{l}\text { CARBUNCLE, FURUNCLE, } \\
\text { etc. }\end{array}$ & 1263 & $16.3 \%(206)$ & 830 & $5.5 \%(46)$ & $<0.001$ \\
\hline COUGH & 1403 & $5.3 \%(75)$ & 8588 & $0.1 \%(5)$ & $<0.001$ \\
\hline CHLAMYDIA INFECTION & 8 & $62.5 \%(5)$ & 899 & 44.4\% (399) & 0.305 \\
\hline ERYSIPELAS & 154 & $66.2 \%(102)$ & 70 & $71.4 \%(50)$ & 0.440 \\
\hline IMPETIGO & 113 & $54.0 \%(61)$ & 2243 & $14.4 \%(322)$ & $<0.001$ \\
\hline $\begin{array}{l}\text { INGROWN NAIL } \\
\text { INFECTION }\end{array}$ & 450 & $22.4 \%(101)$ & 1150 & $8.2 \%(94)$ & $<0.001$ \\
\hline LYME BORRELIOSIS & 42 & $85.7 \%(36)$ & 130 & $80.0 \%(104)$ & 0.408 \\
\hline $\begin{array}{l}\text { MYCOPLASMA } \\
\text { GENITALIUM }\end{array}$ & 28 & $60.7 \%(17)$ & 404 & $31.2 \%(126)$ & 0.001 \\
\hline PHARYNGO-TONSILLITIS & 856 & $61.8 \%(529)$ & 3960 & $14.1 \%(558)$ & $<0.001$ \\
\hline PNEUMONIA & 533 & $67.0 \%(357)$ & 593 & $1.2 \%(7)$ & $<0.001$ \\
\hline $\begin{array}{l}\text { UNSPECIFIED SKIN } \\
\text { INFECTION }\end{array}$ & 595 & $48.2 \%(287)$ & 1743 & $15.7 \%(273)$ & $<0.001$ \\
\hline $\begin{array}{l}\text { UPPER RESPIRATORY } \\
\text { TRACT INFECTION }\end{array}$ & 3193 & $6.6 \%(211)$ & 17,760 & $0.3 \%(50)$ & $<0.001$ \\
\hline
\end{tabular}

In the case of acute cystitis, antibiotics were prescribed during $83 \%$ of physical visits and $78 \%$ of digital visits. It was also examined if one and the same individual sought digital care for cystitis several times. During the two months of the study period, the number of visits per patient was 1,03 , and during the whole year $2020-1,16$.

Logistic regression with the antibiotic prescription as an outcome was performed showing that during the visits to the $\mathrm{PHC}$, antibiotics were prescribed with an Odds ratio of 4.88 relative to the digital visits. 


\section{Discussion}

This study has shown that there were statistically significant differences in antibiotic prescription patterns between digital care and regular care in PHC. Antibiotic prescribing rates for infectious diseases were found statistically significantly lower for digital care in thirteen of the seventeen infections studied. Various respiratory infections were very rarely treated with antibiotics by digital care compared to physical visits at PHC. This was also the case with various skin infections, with the exception of acne, Lyme borreliosis and erysipelas which were treated to the same extent. In addition, the logistic regression showed that the chance of receiving a prescription for antibiotics was 4.88 times higher during visits to the PHC than during the virtual healthcare meetings. Finally, digital care providers appear to be following STRAMA's recommendations regarding the prescribing of antibiotics, despite the fact that the antibiotic prescription limit for all infectious diseases for digital healthcare providers which is set at a maximum of $5 \%$, is not always possible or likely to be met [45].

There is no similar study that examines the conditions that exist in Sweden, although there are a couple of international studies. A study, which investigated twenty various diagnoses, showed that there was no difference in prescriptions, labs and images ordered by online doctors and physicians met in person [30]. Another study also found no difference in prescribing of antibiotics among acute respiratory infection patients who had virtual visits compared to physical visits [28]. Another study stated that national guidelines for urinary tract infections were followed during DTC telemedicine and digital visits and found no difference in antibiotic prescribing patterns [29]. Other studies have found differences; that adult patients presenting with sinusitis, received a lower rate of antibiotic prescribing during online visits compared with in-person visits [27]. And the opposite result was found in one study where it was found that antibiotic prescribing was higher for DTC telemedicine among children 0-17 years compared with urgent care and primary care provider offices [32].

Uncomplicated urinary tract infection (acute cystitis) can be diagnosed during online visits and treated with first-line antibiotics: nitrofurantoin and pivmecillinam without prior sampling. Exceptions apply to pregnant women, children, men and to patients with recurrent cystitis who should undergo further examination. The goal is to treat more than $95 \%$ of diagnosed cases with first-line antibiotics [45]. Antibiotics were prescribed during $83 \%$ of physical visits and $78 \%$ of digital visits. It was then checked if one and the same individual sought digital care for cystitis several times, but this was not the case. This is important due to the fact that if a patient seeks medical care for cystitis several times, this can imply recurrent cystitis and in such case the patient should be examined thoroughly or get a referral to a specialist [45]. During the two months of the study period, the number of visits per individual was only 1,03 , whereas when looking at the whole year 2020 , the number of visits per person was 1,16 .

Certain types of antibiotics should not be prescribed during online visits, especially fluoroquinolones. Antibiotics for which prescriptions should be limited during virtual visits include in particular: amoxicillin and beta-lactamase inhibitor (J01CR02), cefadroxil (J01DB05), sulfamethoxazole and trimethoprim (J01EE01), macrolides (J01FA) [45]. None of the above antibiotics are among the first six most common 
antibiotics prescribed during digital visits. Moreover, the most commonly prescribed antibiotics during virtual visits accounted for $95.4 \%$ of all prescribed antibiotics.

The characteristics of individuals seeking medical help differed for physical versus digital visits. Online visits were common among residents of large metropolises. Both age and sex played an important role as well. Among physical visits, the highest proportion of patients was between 60 and 80 years old.

Whereas virtual visits were mainly used by women in their twenties and by parents of small children. That older people seek medical help more often at the PHC than online may be because of the fact that they suffer from several diseases and are more often in need of submitting blood samples. On the other hand, young people using digital care, who do not want to spend time at clinics, have more often easier ailments or are in need of getting a prescription. Confounding by indication, meaning in this case that for serious illnesses it is more appropriate and more likely that patients seek medical help at PHC rather than online, has been adjusted for by performing logistic regression [46].

This study demonstrates that under the period of study private digital healthcare providers and their online physicians did not prescribe more antibiotics than doctors at PHC, which is the opposite of what has been reported in the media $[8,9,10,11]$. Digital visits have several advantages, the most important of which is quick access. Virtual visits save time for the patients and are comfortable, suitable, and sufficient for making simpler diagnoses and issuing prescriptions. During the COVID-19 pandemic online visits are highly appreciated.

The disadvantages of digital visits are that they are mainly used by inhabitants of large metropolitan areas and by younger individuals. Another weakness of digital healthcare is that patients cannot be properly examined during online visits, which is the case with tonsillitis, pneumonia, and ear infections. Due to this fact, a patient will rarely get antibiotic prescription during an online visit, even if the person needs to be prescribed antibiotics and as a result will be sent to PHC to get treatment. This can be one possible explanation as to why antibiotic prescribing is more common in physical primary care. Overall, it appears that online physicians fill a gap in the Swedish healthcare system by working quite well together with and complementing each other.

\section{Methodological considerations and future studies}

The study has its strengths and limitations. What is good is the large amount of data available, which is in the form of registered healthcare visits. This means that more visits were obtained than if the study had been conducted at the individual's level. However, it is unknown how diagnosis codes were reported, both during online visits and during physical visits at PHC. Possible bias when it comes to diagnoses is that there may be differences in choosing a diagnosis that justifies prescription of antibiotics. In addition, it is not known what was said during both physical and virtual visits, which makes it difficult to understand the doctors' treatment approach. For example, it may be important to have information about allergy to antibiotics in order to better understand why in some cases other antibiotics were chosen than those STRAMA recommends as first-line antibiotics. Another aspect is that it is unknown which of the 
visits were the follow-up visits and which physical visits were the result of the online doctor instructing the patient to seek medical care at the clinic. Region Sörmland, lacking large metropolitan areas, is not fully geographically representative of the whole of Sweden. However, the residents of Region Sörmland account for $2.9 \%$ of Sweden's population [47]. It would of course be better if one had access to and could compare all national data in terms of physical visits to the $\mathrm{PHC}$ with all national data concerning digital visits. Lastly, the study looked at antibiotic prescribing for infectious diagnoses, which limits the generalizability of its results to other diagnoses.

The study provides important insight into the antibiotic prescribing patterns of virtual doctors compared to physicians at PHC, but with its limitations in mind, one can also get guidance for future research. It would be interesting to look at all the national data. One could look at the prescriptions for all medications and for all diagnoses. Future studies could also examine the prescribing of narcotic drugs and whether there is a difference between digital doctors and physicians at PHC.

\section{Conclusion}

The study was based on a large amount of data with 332,987 visits, made by 248,076 individuals. However, substantial differences have been noticed in the characteristics of patients who seek virtual medical help and patients who rather have physical visits at PHC.

This study has shown that private digital care providers do not prescribe more antibiotics than doctors at PHC. On the contrary, probability of receiving antibiotic prescription during digital visits was 4.88 times lower compared to visits to the PHC in Region Sörmland. This seems reasonable given the opportunities that online doctors have and that it is not always possible to examine the patient properly via a video consultation.

\section{Declarations}

\section{Ethical Statement}

The study was carried out in accordance with relevant guidelines and regulations. The study was approved by the Swedish Ethical Review Authority, diary number 2020-04098.

This is a retrospective database registry study analyzing data from existing regional and national databases on health care consumption in Sweden. Data is provided into the databases by health care providers according to national legislation and the data included therein may be used for research without individual informed consent. All sensitive patient data was encrypted using a key code. Thus, the personal integrity of the studied patients was not affected and the study was an observational study without any form of intervention.

\section{Competing Interest:}


The authors report no competing Interest.

\section{Author Contributions:}

J.I, T.W and A.W wrote the main manuscript text and J.I prepared figures and made the calculations together with the statistician.

\section{Funding:}

The study was funded by Centre for Clinical Research Sörmland, Uppsala University, Eskilstuna Sweden and Umeå University

\section{Acknowledgments:}

Special thanks to Nicklas Pihlström, a statistician at Centre for Clinical Research Sörmland, for his excellent statistical work. We would also like to express our gratitude to Kent Bobits at The Health Selection Staff, Region Sörmland for his valuable remarks and good advice.

\section{References}

1. Becevic M, Sheets LR, Wallach E, McEowen A, Bass A, Mutrux ER, et al. Telehealth and Telemedicine in Missouri. Mo Med. 2020 May-Jun;117(3):228-234.

2. McGrail KM, Ahuja MA, Leaver CA. Virtual Visits and Patient-Centered Care: Results of a Patient Survey and Observational Study. J Med Internet Res. 2017 May 26;19(5):e177.

3. Donelan K, Barreto EA, Sossong S, Michael C, Estrada JJ, Cohen AB, et al. Patient and clinician experiences with telehealth for patient follow-up care. Am J Manag Care. 2019 Jan;25(1):40-44.

4. Blix M, Jeansson J. Nätläkare i primärvården - lindring eller lidande?, Ekonomisk debatt, 2018;46(3), p.66-78.

5. Weilenmann L, Söker vård i mataffären: reportage. Vårdfokus, 2019 (11), p.38-41.

6. Han SM, Greenfield G, Majeed A, Hayhoe B. Impact of Remote Consultations on Antibiotic Prescribing in Primary Health Care: Systematic Review. J Med Internet Res. 2020 Nov 9;22(11):e23482.

7. Antibiotikaförskrivning vid digitala vårdmöten. Swedish Agency For Health Technology Assessment And Assessment Of Social Services website. Available from: https://www.sbu.se/en/publications/responses-from-the-sbu-enquiry-service/antibioticprescription-during-e-visits/, [published 2017-01-27, cited 2020-10-09] .

8. Cederberg J. Nätläkare förskriver antibiotika på »dåliga grunder«, Läkartidningen. 2017;114:EPFM.

9. Persson E. Granskning: Nätläkare ställer felaktiga diagnoser. Dagens Arena website. Available from: https://www.dagensarena.se/innehall/granskning-natlakare-staller-felaktiga-diagnoser/, [published 2017-05-16, cited 2020-10-13].

10. Cederberg J. Nätläkare: »Kollegor har en konstig föreställning om vad vi gör«, Läkartidningen. 2019;116:FS6H. 
11. Larsson A. Risker med nätläkare - nu ska de granskas. Swedish Radio website. Available form: https://sverigesradio.se/artikel/7137117, [published 2019-01-22, cited 2020-10-11].

12. Förutsättningar finns för en patientsäker digital vård. The Health and Social Care Inspectorate website. Available from: https://www.ivo.se/publicerat-material/nyheter/nyheter2019/forutsattningar-finns-for-en-patientsaker-digital-vard/, [published 2019-09-12, cited 2020-1010].

13. Vad är primärvård? Capio website. Available from: https://capio.se/capio-vardenheter/primarvard/, [cited 2020-10-15].

14. Health- and sickness Law (2017:30). The Government Offices' legal databases website. Available from: http://rkrattsbaser.gov.se/sfst?bet=2017:30, [published 2017-02-09, cited 2020-10-15].

15. Calles H. Receptskrivningsregler [Internet]. In: Läkemedelsboken, 2018-2019, Läkemedelsverket. Available from: https://lakemedelsboken.se/kapitel/regelverket_och_itstod/receptskrivningsregler.html, [updated 2018-11-30, cited 2020-10-16].

16. Statistik om läkemedel. National Board of Health and Welfare website. Available from: https://www.socialstyrelsen.se/statistik-och-data/statistik/statistikamnen/lakemedel/, [published 2020-04-02, cited 2020-10-16].

17. Karlsson J. Nätläkarna går samman mot statlig utredning: "Saknar förståelse". Digital website. Available from: https://digital.di.se/artikel/natlakarna-gar-samman-mot-statlig-utredning-saknarforstaelse, [published 2020-01-14, cited 2020-10-16].

18. Blix M, Jeansson J. Telemedicine and the Welfare State: The Swedish experience [Internet]. Research Institute of Industrial Economics website. Available from: https://www.ifn.se/eng/publications/wp/2018/1238, [published 2018-10-09, cited 2020-10-19].

19. Cederberg J. SKL sänker ersättningen till digitala vårdgivare. Läkartidningen. 2019;116:FRUE.

20. Data from Centre for Clinical Research (Swedish: Centrum för Klinisk Forskning -CKF) in Region Sörmland.

21. Sjögreen J, Andersson O, Åsberg H. Nätläkare - en affärsidé som skapar problem. Läkartidningen. 2017;114:EF6Y.

22. Wisterberg E. Digitala striden om läkarbesök hårdnar [Internet]. Svenska Dagbladet website. Available from: https://www.svd.se/den-digitala-striden-om-lakarbesok-hardnar, [published 2020-0117, cited 2020-10-19].

23. Översyn av begränsningar för att få tillstånd att bedriva öppenvårdsapotek. Report of Swedish Medical Products Agency, 2019-09-26, Dnr: 4.3.1-2019-019711, p.19.

24. Köpa antibiotika på nätet. Swedish Medical Products Agency website. Available from: https://www.lakemedelsverket.se/sv/behandling-och-forskrivning/kopa-anvanda-och-hantera/kopamedicin/kopa-medicin-pa-natet/kopa-antibiotika-pa-natet, [updated 2020-10-20, cited 2020-10-23].

25. Antibiotika och antibiotikaresistens. Public Health Agency of Sweden website. Available from: https://www.folkhalsomyndigheten.se/smittskydd-beredskap/antibiotika-och-antibiotikaresistens/, [updated 2020-09-14, cited 2020-10-23]. 
26. STRAMA - Samverkan mot antibiotikaresistens. STRAMA website. Available from: https://strama.se/, [updated 2020-10-21, cited 2020-10-23].

27. Johnson KM, Dumkow LE, Burns KW, Yee MA, Egwuatu NE. Comparison of Diagnosis and Prescribing Practices Between Virtual Visits and Office Visits for Adults Diagnosed With Sinusitis Within a Primary Care Network. Open Forum Infect Dis. 2019 Oct 5;6(9):ofz393.

28. Yao P, Clark S, Gogia K, Hafeez B, Hsu H, Greenwald P. Antibiotic Prescribing Practices: Is There a Difference Between Patients Seen by Telemedicine Versus Those Seen In-Person? Telemed J E Health. 2020 Jan;26(1):107-109.

29. Rastogi R, Martinez KA, Gupta N, Rood M, Rothberg MB. Management of Urinary Tract Infections in Direct to Consumer Telemedicine. J Gen Intern Med. 2020 Mar;35(3):643-648.

30. Norden JG, Wang JX, Desai SA, Cheung L. Utilizing a novel unified healthcare model to compare practice patterns between telemedicine and in-person visits. Digit Health. $2020 \mathrm{Sep}$ 17;6:2055207620958528.

31. Sood A, Watts SA, Johnson JK, Hirth S, Aron DC. Telemedicine consultation for patients with diabetes mellitus: a cluster randomised controlled trial. J Telemed Telecare. 2018 Jul;24(6):385-391.

32. Ray KN, Shi Z, Gidengil CA, Poon SJ, Uscher-Pines L, Mehrotra A. Antibiotic Prescribing During Pediatric Direct-to-Consumer Telemedicine Visits. Pediatrics. 2019 May;143(5):e20182491.

33. Öppna jämförelser - Miljöarbetet 2020 i regionerna [Internet]. Sweden's Municipalities and Regions website. Available from: https://rapporter.skr.se/oppna-jamforelser--miljoarbetet-2020-iregionerna.html, [cited 2020-11-06].

34. Hedlund F. Vart fjärde antibiotikarecept har försvunnit på tio år. Svensk farmaci website. Available from: https://svenskfarmaci.se/lakemedel/vart-fjarde-antibiotikarecept-har-forsvunnit-pa-tio-ar/? fbclid=IwAR2DHcLhcVW58FGUIYDdF1sabflJUGwiM8iadjh_JVhpB9nmEX3NLqIKeHAp, [published 2020-11-05, cited 2020-11-06].

35. European Centre for Disease Prevention and Control. Antimicrobial consumption in the EU/EEA, annual epidemiological report for 2018. Stockholm: ECDC; 2019.

36. Fass i vårdens system. FASS website. Läkemedelsindustriföreningen, Lif. Available from: fass.se, [updated 2019-11-19, cited 2020-11-07]. (FASS is an abbreviation for: Pharmaceutical Specialties in Sweden, its website contains information on all approved drugs in Sweden, for humans and animals).

37. Drug statistics database. Reached via website of the National Board of Health and Welfare. Available from: https://sdb.socialstyrelsen.se/if_lak/val.aspx.

38. Hahlin A, Nordqvist $O$. Användning av antibiotika och handläggning av infektioner. STRAMA website. Available from: http://strama.se/wp-content/uploads/2018/04/Antibiotika-och-infektioner-2018-0322-AH-ON.pdf, [published 2018-04-04, cited 2020-11-08].

39. WHO Collaborating Centre for Drug Statistics Methodology website. Available from: https://www.whocc.no/atc_ddd_index/?code=J01\&showdescription=no, [cited 2020-11-02]. 
40. Att följa upp förskrivning av antibiotika i primärvård, en vägledning. Public Health Agency of Sweden website. Available from: https://www.folkhalsomyndigheten.se/publiceratmaterial/publikationsarkiv/a/att-folja-upp-forskrivning-av-antibiotika-i-primarvard-en-vagledning/, [published 2016-06-21, cited 2020-11-08].

41. Ejlertsson G. Statistik för hälsovetenskaperna. 2nd ed. Lund: Studentlitteratur; 2012, p.189-195.

42. IBM Corp. Released 2013. IBM SPSS Statistics for Windows, Version 22.0. Armonk, NY: IBM Corp.

43. Law (2003:460) on ethical review of research concerning humans. The Swedish Parliament website. Available from: https://www.riksdagen.se/sv/dokument-lagar/dokument/svenskforfattningssamling/lag-2003460-om-etikprovning-av-forskning-som_sfs-2003-460, [published 200306-05, cited 2020-11-30].

44. Vad säger lagen? Swedish Ethical Review Authority website. Available from: https://etikprovningsmyndigheten.se/for-forskare/vad-sager-lagen/, [cited 2020-11-30].

45. Rekommendationer för kvalitetsindikatorer vid digitala vårdmöten 2019. STRAMA website. Available from: https://strama.se/nyheter/kvalitetsindikatorer-for-digitala-vardmoten/, [updated 2019-10-31, cited 2020-12-22].

46. Pourhoseingholi MA, Baghestani AR, Vahedi M. How to control confounding effects by statistical analysis. Gastroenterol Hepatol Bed Bench. 2012 Spring;5(2):79-83.

47. SCB website (Statistics Sweden). Available from: https://www.scb.se/hitta-statistik/statistik-efteramne/befolkning/befolkningens-sammansattning/befolkningsstatistik/,[updated 2020-11-10, cited 2021-01-12].

\section{Figures}

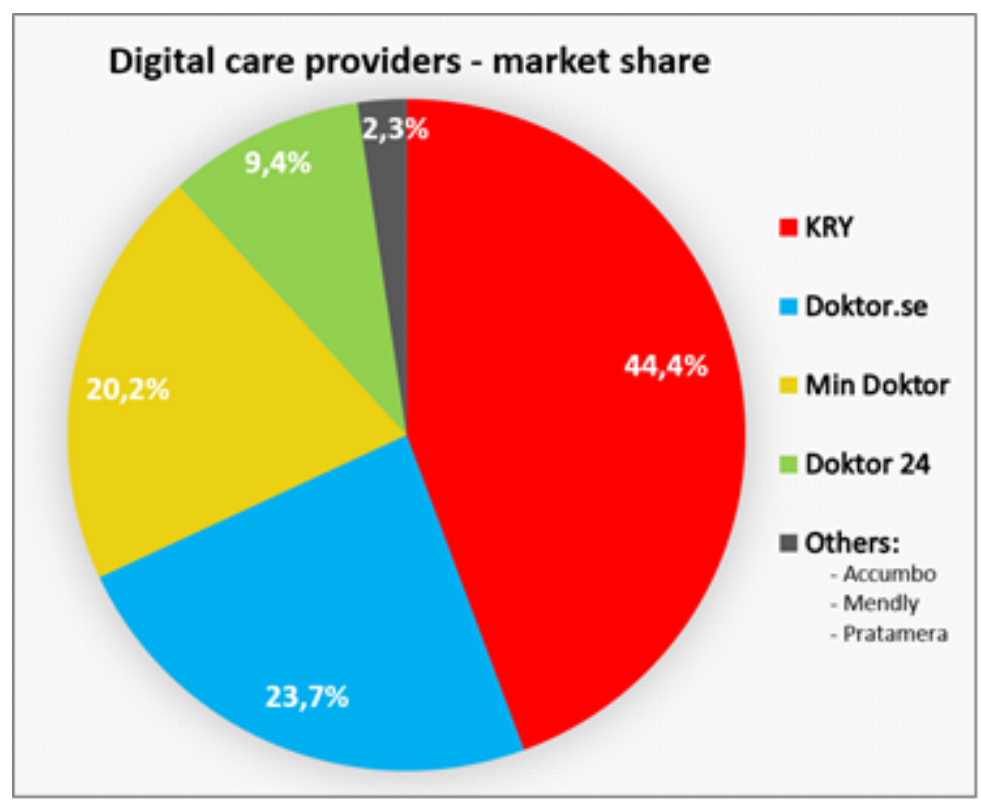

Figure 1 
Private digital care providers and their market share in Jan-Feb 2020 [data from Centre for Clinical Research, Region Sörmland]

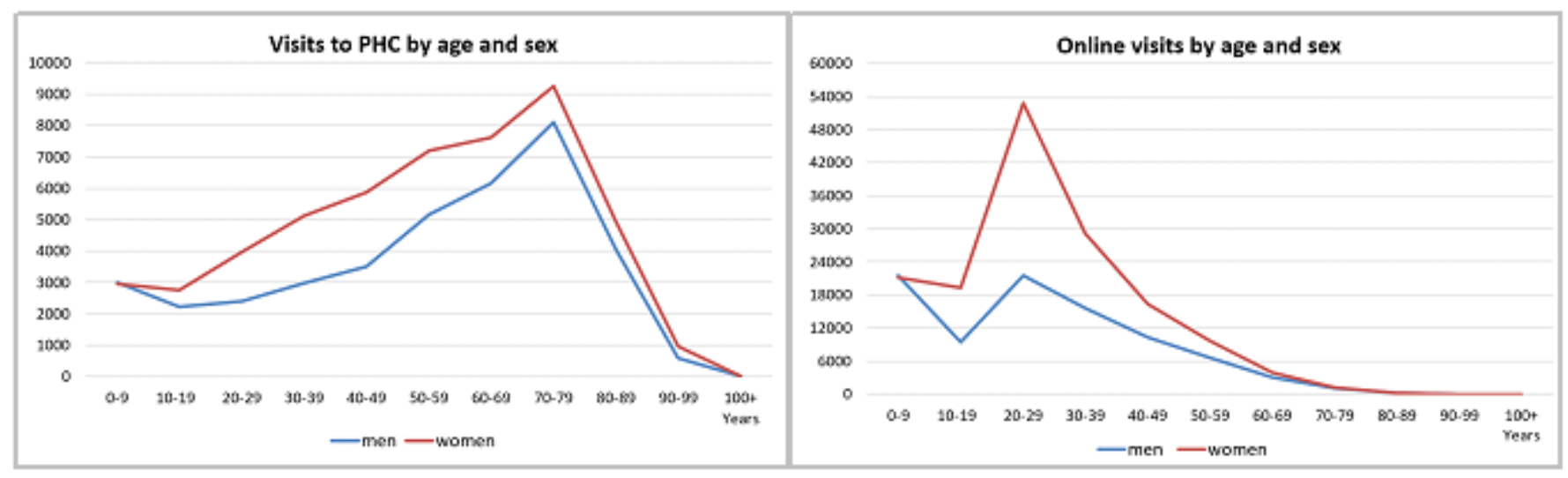

\section{Figure 2}

In-person \& online visits by age categories for men and women

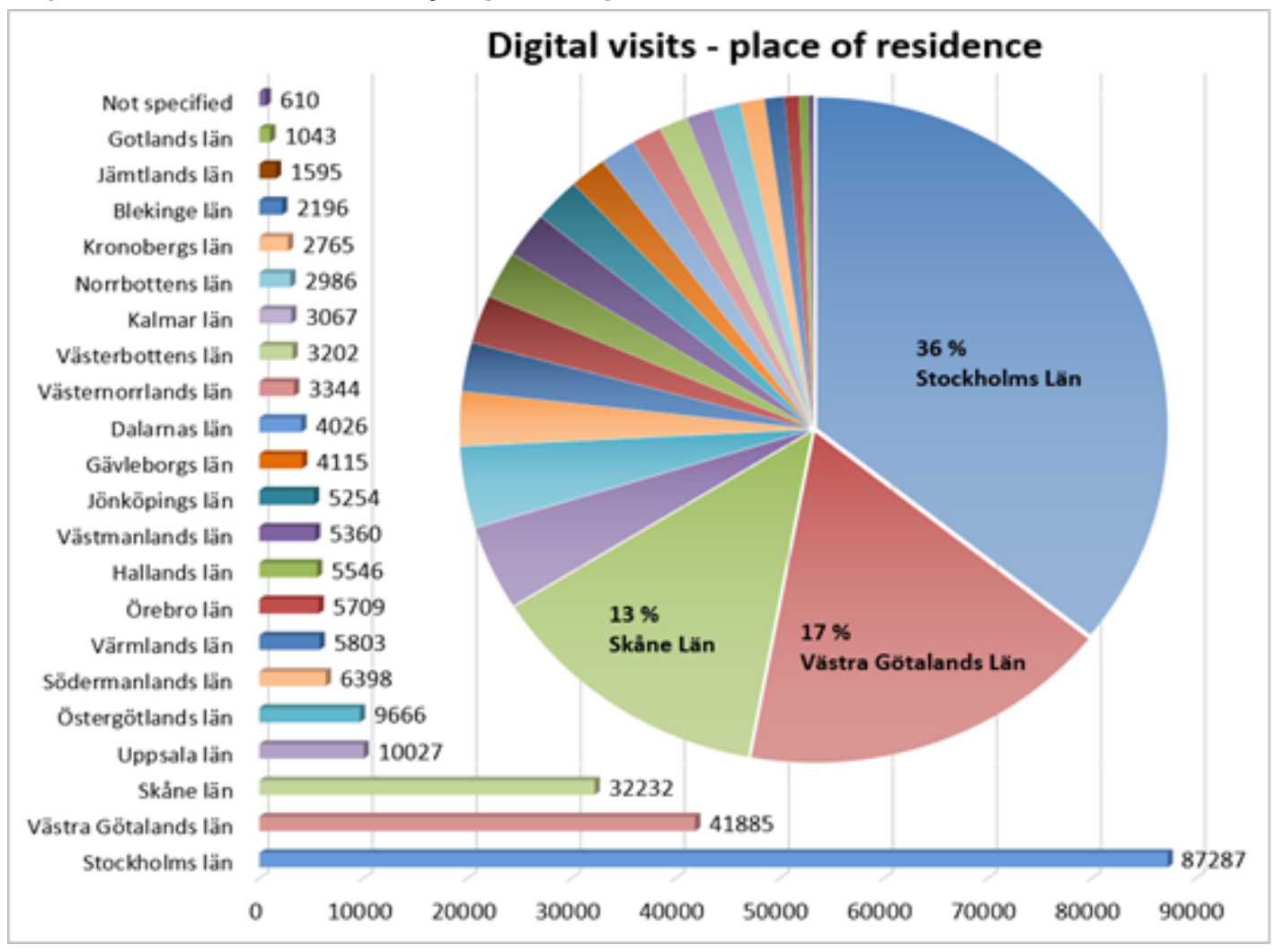

\section{Figure 3}

Online visits (Jan-Feb 2020) - by county residence 